\title{
Health as Human Rights under Malaysian National Legal Framework
}

\author{
Md. Zahidul Islam \\ LL.B (Eastern University), MCL (IIUM), Postgraduate Student, Ahmad Ibrahim Kulliyyah of Laws, \\ International Islamic University Malaysia
}

\begin{abstract}
Good health is fundamental to a full and active life. It is the key to wealth and prosperity. Good health contributes directly to economic growth while poor health drives poverty. The right to health is considered directly in many international instruments including the World Health Organization. Every single country in the world is now a member of at least one of the many international instruments where health is treated as a human right. Sound health is a pre-condition to enjoy right to live peaceful. This right to health is guaranteed by the Federation Constitution of Malaysia. If anybody in Malaysia is deprived of enjoying his life then he can go to the court in order enforce his right. This paper aims at giving an overview of legal and regulatory framework of different international legal instruments and national laws of Malaysia relating to healthcare and shares the response of Malaysia Government in relation to the framework.

Keywords: Health, Fundamental Rights, Human Rights, International Human Rights Instruments, World Health Organization, Laws of Malaysia.
\end{abstract}

Accepted Date: 24 June 2013

\section{Introduction}

In the Oxford dictionary, 'health' is defined as "the state of being well and a state free from illness in body or mind." It also implies the condition of a person body or mind. ${ }^{2}$ It is the extent of continuing physical, emotional, mental, and social ability to handle with one's environment. ${ }^{3}$ The WHO Constitution of 1946 describes health as "a state of complete physical, mental and social well-being and not merely the absence of

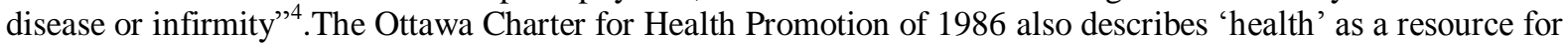
everyday life, not the objective of living. Health is a affirmative concept emphasizing social and personal resources, as well as physical capacities." According to the WHO' definition, health is defined in terms of ultimate goal of perfection. The WHO has also specified particular objectives to be reached on the way to this ideal. ${ }^{6}$ Article I of the Alma-Ata Declaration of 1978 defines health as "a state of complete physical, mental and social 11 well being, and not merely the absence of disease or infirmity." "Actually, it is very difficult to find the universal definition of the term 'health'. There is no law which directly defines 'health'.

Human rights are universally inherent, inalienable and inviolable rights of all mankind. States and their public authorities must ensure human rights for the people. ${ }^{8}$ Human rights are concerned with the dignity and worth of the individuals and "represent minimal moral standards for human society."

On the basis of the three watchwords of the French Revolution such as Liberty, Equality and Fraternity, the Czech jurist, Carel Vasak divided human rights into three generations. The first-generation concerns with

\footnotetext{
${ }^{1}$ See OXFORD ADVANCED LEARNER'DICTIONARY WITH WORKSHEETS 551 (5th ed. 1999).

Id.

${ }^{3}$ See 4 BRITANNICA READY REFERENCE ENCYCLOPEDIA (India) 276 (2005).

${ }^{4}$ The Constitution of the World Health Organisation ("WHO Constitution"), Pmbl. (2nd Para.)

${ }^{5}$ The Ottawa Charter for Health Promotion (adopted at the First International Conference on Health Promotion on

Nov. 12, 1986) See WHO/HPR/HEP/95.1, available at http://www.who.int/hpr/NPH/docs/ottawa_charter_hp.pdf (last visited on Nov. 11, 2008).

${ }^{6}$ WHO, TARGETS FOR HEALTH FOR ALL: TARGETS IN SUPPORT OF THE REGIONAL STRATEGY FOR HEALTH FOR ALL BY THE YEAR

2000 (1985). For a commentary on this document, see D. Sharp, Health for All by the Year 2000: Information Targets. National Goals?-No National Targets? , 4 H EALTH L IBRARIES R EV . 219-224 (1987), available at http://onlinelibrary.wiley.com/doi/10.1046/j.1365-2532.1987.440219.x/pdf (last visited on July 31, 2010).

${ }^{7}$ The Alma-Ata Declaration (1978), art.1, available at http://www.who.int/hpr/NPH/docs/declaration almaata.pdf (last visited on July 31, 2010).

${ }^{8}$ ERSHADUL BARI, HUMAN RIGHTS AND WORLD PEACE 1 (DHAKA UNIV. STUD., Pt.F, vol. III, 1992).

${ }^{9}$ Morris B. Abram, Freedom of Thought, Conscience and Religion, 8 J. INT' COMM' OF JURISTS 40 (1967), quoted byLN Bari, supra note 12 .
} 
civil and political rights. They were the brain child of Western democratic countries. The first-generation includes right to life, liberty, security to persons, freedom of assemble, freedom of association, and freedom of religion. The second-generation focuses on economic, social and cultural rights. They were traditionally supported by socialist countries. The second-generation of human rights discourse includes right to employment, right to housing, and right to equal wage. The third generation human rights emerge with the United Nations with the Stockholm Declaration on the Human Environment. The third-generation of human rights includes group and collective rights, such as right to self-determination right to environment and right to development. ${ }^{10}$

\section{International Legal Instruments for Health:}

Article 25 of the Universal Declaration of Human Rights of 1948 ("UDHR") provides that "everyone has the right to a standard of living adequate for the health and well-being of himself and his family including food, clothing, and medical care." Second, Article 12 of the International Covenant on Economic, Social and Cultural Rights of 1966 ("ICESCR") provides that "the States being Parties to the present Covenant recognize the right of everyone to the enjoyment of the highest attainable standard of physical and mental health."This article also provides that "in doing so the state parties shall take necessary steps to ensure reduction of the stillbirth-rate of infant mortality and for the healthy development of the child; to improve all aspects of environmental and industrial hygiene; to prevent, treat and control epidemic, endemic, occupational and other diseases; and create conditions which would assure to all medical service and medical attention in the event of sickness."The Universal Declaration on the Human Genome and Human Rights of 1997 contains similar provisions relating to health. ${ }^{11}$ Third, point 11 of Part I of the European Social Charter of 1961 provides that "everyone has the right to benefit from any measures enabling him to enjoy the highest possible standard of health attainable."Point 12 of Part II of the European Social Charter of 1961 dealing with the right to protection of health also provides that "[w]ith a view to ensuring the effective exercise of the right to protection of health, the Contracting Parties undertake, either directly or in co-operation with public or private organizations, to take appropriate measures designed inter alia: (1) to remove as far as possible the causes of ill-health; (2) to provide advisory and educational facilities for the promotion of health and the encouragement of individual responsibility in matters of health; and (3) to prevent as far as possible epidemic, endemic and other diseases. Fourth, Article XI of the American Declaration of the Rights and Duties of Man of $1948{ }^{12}$ provides that "every person has the right to the preservation of his health through sanitary and social measures relating to food, clothing, housing and medical care, to the extent permitted by public and community resources."Fifth, Article 16 of the African [Banjul] Charter on Human and Peoples' Rights of 1981 provides that "every individual shall have the right to enjoy the best attainable state of physical and mental health."The African Charter on Human and Peoples' Rights also made it obligatory for State Parties to take necessary measures to protect the health of their people and to ensure that they receive medical attention when they are sick. Sixth, Article 13 of the Arab Charter on Human Rights of 1994 and Article 3 of the Commonwealth of Independent States Convention on Human Rights of 2000 prohibit medical or scientific experimentation on any person without his free consent.

According to those in instruments and resolutions, the health-related issue is demanding more attention from the international community. Noticeable is that the Universal Declaration on Human Rights links health to the standard of living, though all other instruments treat health as an independent right to life in general. Though most international human rights instruments only deal with physical health, then ICCPR includes both 'physical' 'mental 'health. ${ }^{13}$ Both the ICCPR and European Social Charter define the right in terms of the 'highest' standard of health 'attainable.'

Together, the International Labour Organization ("ILO") adopted many conventions relating to occupational safety and health. They are as follows: the Convention on Medical Examination of Young Persons (Industry) of 1946 (Convention No. 77), the Convention on Medical Examination of Young Persons (NonIndustrial Occupations) of 1946(Convention No. 78), the Convention on Employment Injury Benefits of 1964 (Convention No. 121), the Convention on Medical Examination of Young Persons (Underground Work) of 1965 (Convention No. 124), the Convention on Occupational Health Services of 1985 (Convention No. 161), the Convention on the Prohibition and Immediate Action for the Elimination of the Worst Forms of Child Labour of 1999 (Convention No. 182), the Convention on the Maternity Protection of 2000 (Convention No.

\footnotetext{
${ }^{10}$ Karim, Md. Ershadul “Health as Human Rights under National and International Law: Bangladesh

Perspective”, Journal of East Asia \& International Law, Vol. 3, No. 2, Autumn 2010, pp. 337-363.

${ }^{11}$ See UNESCO Gen. Conf. Res. 29 C/Res.16, reprinted in Records of the General Conference, UNESCO, 29th Sess.,

29 C/Res. 19, at 41 (1997) (adopted by the UN General Assembly, G.A. Res. 152, U.N. GAOR, 53rd Sess., U.N. Doc. A/RES/53/152 (1999)).

${ }^{12}$ O.A.S. Res. XXX (adopted by the 9th International Conference of American States of 1948), reprinted in Basic

Documents Pertaining to Human Rights in the Inter-American System, OEA/Ser.L.V/II.82 Doc.6 rev.1, at 17 (1992).

${ }^{13}$ ICCPR, art. 12.
} 
$183) .^{14}$

\section{Implementation of Health Related Issues in Malaysia:}

A. A Short History of Health Administration in Malaysia

World Health Organization (WHO) has been active in Malaysia since the time of Malaysia gained independence in 1957. WHO and Ministry of Health signed the basic agreement for collaboration in 1961 and established the WHO country representative office. After this, Malaysia agreed to observe all of these principles and to implement these at the national level. Before accepting the world standard, Malaysia had maintained noticeable tradition on health and medical care. They used to with Malay Traditional Medicine, Chinese Traditional Medicine, Indian Ayurveda Medicine, Homeopathy Medicine. ${ }^{15}$ The root of Chinese Traditional Medicine (also referred to as TCM) dated back more than 2000 years. ${ }^{16}$ At the time of the Vedas (c 1500-500 BC), Ayurveda (meaning the "Science of life"), medicine was practiced. It was followed by Homeopathy between 1810 and 1839 AD.

\section{B. Health Issues in the Federal Constitution of Malaysia}

The Federal Constitution of Malaysia considers the health issues very seriously. The Federal Constitution extensively covers this issue. Part-II (Art.5-13) of Federal Constitution of Malaysia discusses about fundamental liberties. Article 5(1) of this part lays down that "No person shall be deprived of his life or personal liberty saves in accordance with law. Part II concerns with judicially enforceable rights subject to such restrictions as mentioned in those provisions. If any of these rights are infringed the victim or the aggrieved person can go to the High Court Division. ${ }^{17}$

Article 9 of the Federal Constitution of Malaysia provides that, Government may impose any restriction (by enactment of law) against the freedom of movement of Malaysia citizen when he is threaten for public health. ${ }^{18}$ Article 11 of the Federal Constitution of Malaysia ensures religious freedom but this freedom not exercise by ignoring public health. ${ }^{19}$ Article 48 of the Federal Constitution of Malaysia specifies that a person is disqualified from being a member of either House of Parliament if he is and has been found or declared to be of unsound mind. ${ }^{20}$ In addition, Article 119 of Federal Constitution of Malaysia also discusses that "a person is disqualified for being an elector in any elector in any election to the House of Representatives of the Legislative Assembly if on the qualifying date he is detained as a person of unsound mind. ${ }^{21}$ Article 125 of Federal Constitution specifies the removal of judge of Federal Court in case of infirmity of body of mind. ${ }^{22}$ The Yang di-Pertuan Agong shall appoint a tribunal and refer the representation to it and may on the recommendation of the tribunal remove the judge from his office. ${ }^{23}$ The intense discussion shows the importance of the health issues even though the enlighten provisions are kept with those rights not being judicially enforceable.

\section{Health Issues in National Laws in Malaysia}

Since the independence in 1957, the Government of Malaysia has passed many laws regarding health issues. $^{24}$ These laws were enacted to serve multiple purposes, ranging from identifying products detrimental for human health64 to making people aware of different diseases, from setting up medical institutions to managing

\footnotetext{
${ }^{14}$ ILO, Database of International Labour Standards, available at http://www.ilo.org/ilolex/english/convdisp1.htm (last visited on July 31, 2010).

${ }^{15}$ Abu Bakar Bin Suleiman, Working for Health 126 (1996).

${ }^{16} \mathrm{http}: / /$ www.amfoundation.org/tcm.htm; http://en.wikipedia.org/wiki/Traditional_Chinese_medicine

${ }_{17}$ Federal Constitution of Malaysia, art.5, para.2. Islam, Md Zahidul. "Legal Enforceability of ADR Agreement."International Journal of Business and Management Invention. Vol.2,No.1,January,2013. pp-40-43

${ }^{18}$ Id. art.9.

${ }^{19}$ Id. art. 11 .

${ }^{20} I d$. art. 48 , para. 1

${ }^{21} I d$. art.119, para.3.

${ }^{22}$ Id. art. 125 , para. 3

${ }^{23} \mathrm{Id}$

${ }^{24}$ Food Act,1983(Act No.281 of 1983; Tobacco Products Control Act,1993 (Act No.83of 1993); Sale Of Drugs Act 1952 ( Revised 1989) (Act No.368 of 1952); Prevention \& Control of Infectious Diseases Act, 1988 (Act No. 342 of 1988); Prevention \& Control of Diseases Regulations (Entry to Malaysia) 1993; Prevention \& Control of Diseases Regulations (Compoundable Offences) 1993; Prevention \& Control of Diseases Regulations (Notice) 1993; Sarawak Public Health Ordinance 1962; Hydrogen Cynaide Act 1953; Methyl Bromide Order 1978; International Health Regulations 1969; Private Hospital Act 1971; Destruction Of Diseases Bearing Insects Act 1975; Local Government Act 1974; Road, Building \& Drainage Act 1974; Uniform Building By Law 1984; Criminal Procedure code( Act No.593); Education Act 1995; School Ordinance 1950; Pesticide Act 1974; Environmental Quality Act,1974 (Act No.127 of 1974); Town and Country Planning Act,1976( Act No.172 of 1976); Atomic Power Licensing Act,1984; Sewage Services Act,1993; Occupation Safety \& Health Act \& Regulations 1993; Town \& Country Planning Act,1976; Workers minimum Standards Of Housing And Amenities Act,1990; Protection Of Public Health Ordinance 1999; Medical Act,1971 (Act No.50 of 1971); Human Tissues Act,1974 (Act No.130 of 1974 ); Telemedicine Act,1997 (Act No.564 of 1997); Child Act,2001 (Act No.611 of 2001); Child Care Centre Act,1984 (Act No.308 of 1984); Child Protection Act,1991 (Act No.468 of 1991); Mental Health Act, 2001 (Act No.615 of 2001); Nurses Act 1950 and Regulations 1985;
} 
human resources involved in health sector. There are other laws concerned with health. For example, the Penal Code; Criminal Procedure code (Act No.593), Local Government Act 1974 and Town and Country Planning Act (Act No.172 of 1976) contain elaborate provisions relating to health. Under section 13(1) of the Malaysian Food Act 1983(Act no.281 of 1983), any person who prepares or sells any food that has in or upon it any substance which is poisonous, harmful or otherwise injurious to health commits an offence and shall be liable. ${ }^{25}$ Moreover, any person who prepares or sells any food that consists wholly or in part of - any diseased, filthy, decomposed or putrid animal or vegetable substance; any portion of an animal unfit for food; or the product of an animal which has died otherwise than by slaughter or as game, whether manufactured or not, commits an offence and shall be liable. ${ }^{26}$ Preparing and selling of adulterated also prohibited. ${ }^{27}$ People have to maintain the standard of the food. If he fails, it will be punishable offence. ${ }^{28}$ If any person convicted for any offence under this Act, Court can give order to cancel his licence. ${ }^{29}$ Tobacco Products Control Act 1993 discusses many issues to protect health. According to this Act, the smoking of tobacco products in any public place is prohibited.$^{30}$ No person shall sell or supply any tobacco product to any person under the age of 16 years. ${ }^{31}$ If any person commit any offence under this Act, he will be liable up to RM $200000 .{ }^{32}$ Under Prevention \& Control of Infectious Diseases Act (Act No.342 of 1988), An authorized officer may enter into and medically examine any vehicle at any time upon its arrival in Malaysia and medically examine any person, animal or article on board such vehicle. ${ }^{33}$ No person shall knowingly import into or export out of Malaysia any human remains, human tissues or part thereof or any pathogenic organism or substance or part thereof. ${ }^{34}$ No person who knows or has reason to believe that any item is contaminated or that any animal is infected or contaminated shall give, lend, sell, transmit, use or expose such item or animal without prior disinfection. ${ }^{35}$ If any person sells any infected animal or items, he will be convicted under this Act. ${ }^{36}$ Section 4 of Hydrogen Cynaide Act 1953 (Ordinance No.22 of 1953) (Act 260) (Revised 1981) said that whenever any accident which occasions loss of human life or personal injury occurs as the result of the fumigation of any premises or article, the person by whom, or by whose agent, the fumigation was carried out shall forthwith send or cause to be sent to the Minister notice of the accident and of the loss of human life or personal injury. Every such person as aforesaid who fails to comply with this section shall, on conviction, be liable to a fine of two hundred ringgit.

Under section 64 of The Protection of Public Health Ordinance 1999, the Protection of Public Health (Licensing of Hotel and Loading Houses) Regulations2003 has adopted. Section 6 of this regulation supposed that- no person shall be permitted to reside or be employed be any premises used as a hotel or loading house who, in the opinion of the Medical Officer of Health or Public Health Officer of the local authority, is suffering from any communicable disease, or is in contract with any such disease. The licensee shall, as soon as it comes to his knowledge that any person on the premises of suffering or is suspected to be suffering from a communicable disease, immediately notify a Medical Officer of Health or a Public Health Officer of the local authority of the circumstances and shall at once isolate the person from coming in contact with articles used by other guests of the hotel or loading house. If any licensee fails to notify Medical officer of Health or a Public Health Officer, he shall be guilty of an offence under this Act. ${ }^{37}$ According to Destruction Of Diseases Bearing Insects Act 1975, Where it appears to the Director General or a Medical Officer of Health or an inspector that any premises or anything therein is likely to propagate or harbour any disease-bearing insects, he may in writing order such owner or occupier to take specified measures or to do any work with regard to the premises or for the treatment, destruction or removal of anything therein as to make the premises or conditions therein unfavourable to the propagation or harbouring of the disease-bearing insects. ${ }^{38}$ Moreover many section of Environmental Quality Act (Act No.127 of 1974), Protection Of Public Health Ordinance 1999, Medical Act (Act No.50 of 1971), Human Tissues Act (Act No.130 of 1974), Telemedicine Act (Act No.564 of 1997), Child Act (Act No.611 of 2001), Mental Health Act (Act No.615 of 2001) discuss about public health protection.

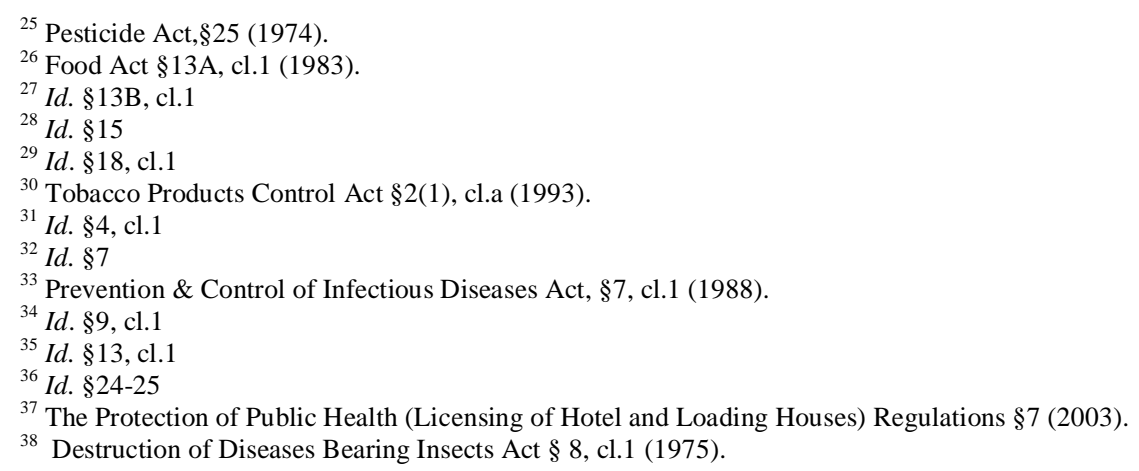




\section{A. Regulatory Framework}

\section{Health Care System}

The Ministry of health $(\mathrm{MOH})$ is the main provider of health care in the public sector, with the rest mainly provided by the Ministry of Education, Ministry of defence, Ministry of Home Affairs, statutory bodies and local authorities. ${ }^{39}$ The Ministry of Health $(\mathrm{MOH})$ is primarily responsible to look after and administer health related issues in Malaysia. Director General of Health is the administrative head of Central Government. He has five sub-ordinates (three Deputy Director General and two Directors) such as Deputy Director-General of Health (Medical), Deputy Director-General of Health (Public Health), Deputy Director-General of Health (Research \& Technical Support), Director (Dental), and Director (Pharmacy). State Health Director is the administrative head of state. He has five deputies. They are Deputy State Health Director (Medical), Deputy State Health Director (Dental), Deputy State Health Director (Public Health), Deputy State Health Director (Pharmacy), and Deputy State Health Director (Management). Medical Officer in-charge is head of district hospital. District Hospital consists of some trained personnel under him. ${ }^{40}$ There are four types of hospitals in public sector under the Ministry of the Health. They are district hospitals, state general hospitals, national referral center and special institutions, and non-MOH hospitals. The district hospitals typically have between 100 and 200 beds and are normally run by 6 to 10 Medical Officers. State general hospitals have 500 to 1500 beds. Each state has one state general hospital except for the state of Sabah, which has two. These hospital provide outpatient and inpatient by both specialist and non- specialist medical officers. The national referral centre is the highest level of hospital in the hierarchy. This has 2800 beds and is located in Kuala Lumpur. It receives referrals from other parts of the country. ${ }^{41}$

\section{B. Health and Local Government}

In Malaysia, the local authority such as city council, municipal council or district council, ${ }^{42}$ play a leading role in administration. The affairs of every local authority area shall be administered by a local authority established by and in accordance with the Local Government Act, 1976(Act No.171 of 1976). ${ }^{43}$ Provided that where in the application of this Act to the Federal Territory there is any conflict between the provisions of this Act and the Federal Capital Act 1960, or the regulations made there under, the provisions of the Federal Capital Act 1960, shall prevail. ${ }^{44}$ All of this local authority shall constitute the Standing Committees for dealing with various social and health issues. ${ }^{45}$ The relevant laws empower the local authority to perform some mandatory and optional duties.

\section{Health Related Issues in Universities}

There are twenty public universities in Malaysia. All of them were established by special laws ${ }^{46}$ which empower the universities to supervise the residence and discipline of the students, and to promote their health. Many public universities have Faculty of Medicine. ${ }^{47}$ There are many private medical universities and colleges. ${ }^{48}$ This medical universities and colleges are developing Malaysia health sector gradually. Unfortunately, however, most of the universities are still far behind the standard to ensure health of students, faculties, officials and staffs. The residential hostels are over-crowded; foods are sub-standard; the adjacent areas to these residential hostels are neither clean nor hygienic.

\section{Health Related Cases before the Malaysian Courts:}

There are many cases were filed in Malaysian Court regarding health. Most of the time, health related cases were filed for medical negligence by the doctor. In Chelliah a/l Manickam \& Anor v. Kerajaan Malaysia ${ }^{49}$, the High Court held that the defendant was vicariously liable for the acts of the doctors at Penang General

\footnotetext{
${ }^{39}$ Abu Bakar Bin Suleiman, Working for Health 125 (1996).

${ }^{40} \mathrm{Id}$. at 175 .

${ }^{41}$ yousigma.com/comparativeanalysis/malaysiahealthcaresystem.pdf

${ }^{42}$ Local Government Act $\$ 2$ (1976).

${ }^{43} I d . \$ 8$.

${ }^{44} \mathrm{Id}$

${ }^{45} I d . \S 28$.

${ }^{46}$ University of Malaya Act (1961); Degrees and Diploma Act (1962); Universities and University Colleges Act (1971); Universiti Teknologi Mara Act (1976);

${ }^{47}$ University of Malaya; International Islamic University Malaysia; Islamic Science University of Malaysia; University of Science Malaysia; National University of Malaysia; Putra University, Malaysia; Sultan Zainal Abidin University; Sabah University of Malaysia;

${ }^{48}$ International Medical University (IMU); Penang Medical College (PMC); Melaka Manipal Medical College (MMMC); Asian Institute of Medicine, Science and Technology (AIMST); Royal College of Medicine Perak (RCMP); University College Sedaya International (UCSI); Allianze College of Medical Sciences (ACMS); Cyberjaya University College of Medical Sciences (CUCMS); Management and Science University (MSU); Mahsa University College; Taylor's University College; University Tunku Abdul Rahman; Masterskill University College of Health Sciences (MUCH); Segi University College; Insaniah University College; Perdana University; Lincoln University College; University College Shah Putra. 
Hospital. The Doctor Involved had wrongly diagnosed an acute perforated appendicitis. The treatment for pancreatitis are different, namely in the case of acute appendicitis, the treatment in surgical intervention whereas for acute pancreatitis is conservative treatment. ${ }^{50}$ In Chin Keow v Government of Malaysia, ${ }^{51}$ a doctor was held negligent for not inquiring the medical history of the patient. In Chin Yoon Hiap (Dr.) v Ng Eu Khoon \& 2 ors, ${ }^{52}$ the plaintiff sued Dr Smith and Dr Chin for negligence and claim damages for pain and suffering and for causing the plaintiff's blindness. The trial judge held that Dr Chin was negligent and he appealed against this decision. On this issue of whether Dr chin was negligent, the Court of Appeal held that he was not. Elizabeth Choo v Government of Malaysia,$^{53}$ in this case, the plaintiff claimed that the anaesthetist was negligent during the pre-operative sigmoidoscopic examination, which had result in the perforation of the colon. One of the issues, which were discussed, in this case was whether it was proper for the anaesthetist to perform sigmoidoscopis examination under general anaesthesia. In this case Court took expert opinion. Then the Court observed that the anaesthetist had previously successfully performed hundreds of sigmoidoscopis examination under general anaesthesia. Thus, applying the Bolam principle ${ }^{54}$ (according to this principle, a doctor is not negligent if he has acted with a practice accepted as proper by a reasonable body of medical men skilled in that particular art. $)^{55}$ to this issue, the court held that the anaesthetist was not negligent as he had followed the general and approved practice in the situation he was facing. The technique he adopted was approved by a reasonable body of medical men since 1956. Therefore, it did not matter if there is another body of opinion that would have taken a contrary view. ${ }^{56}$ On the other hand, in Kamalam a/p Ruman \& Ors v Eastern Plantation Agency (Johore) Sdn Bhd Ulu Tiram Estate, Ulu Tiram, Johore \& Anor, ${ }^{57}$ the court refused to apply the Bolam Principle. In this case, the defendant doctor failed to diagnose the plaintiff's aliment, which turned out to be a stroke. The court found that the doctor had falled below the standard of care required of him in failing to admit the plaintiff into the hospital and thereby, causing his death.

A ruling was declared by the Federal Court in Foo FioNa v Dr Soo fook Mun \& Anor ${ }^{58}$ that, the practitioner is duly bound by law to inform his patient who is capable of understanding and appreciating such information of the risk involved in any proposed treatment so as to enable the patient to make an election of whether to proceed with the proposed treatment with knowledge of the risks involved or decline to be subjected to such treatment. ${ }^{59}$

\section{E. National Health Policy:}

The Federal Government of Malaysia follows the Russian system of five-year plans. Every plan contains a chapter on health issue. First Malaya plan was adopted for five years from 1956 to 1960. Now Tenth Malaysia Plan has adopted for five years. It has stated from 2011 and it will continue until 2015. The 10MP has targeted a gross domestic product (GDP) growth of $6 \%$ per annum over the next five years, which will be led by the private sector and underpinned by the services sector. Gross national income per capita is projected to rise to US\$ 12,139 (about RM 40,000) by 2015, from US\$ 8,256 in 2010. The pivotal aim of the 10MP is in reenergizing the private sector by putting in place a conducive environment, including facilitating an economy that will have a more level playing field and which would rely on greater use of intellectual capital, skills, innovation and technology. Emphasis will also be placed on drawing in more foreign direct investment (FDI), especially into small and medium sized enterprises (SMEs). Currently SMEs make up $99.2 \%$ of all business in Malaysia, contributing 56.4\% of total employment and some 31\% to GDP. The total development allocation under the 10MP is RM230 Billion, of this 55\% percent is for the economic sector, $30 \%$ for the social sector, $10 \%$ for security and $5 \%$ for general governance (Figure D). Also a bigger portion of the 10MP development expenditure will be allocated for non-physical programmes, rising from $22 \%$ to $40 \%$ in the $10 \mathrm{MP} .{ }^{60}$ Moreover, already Malaysia Government has declared Vision 2020. The Prime Minister, in February 1991 stated Vision 2020 as:

"By the year 2020, Malaysia is to be a United Nation with a confident Malaysian society infused by strong moral and ethical values, living in a society that is democratic liberal and tolerant, caring, economically just and equitable, progressive and prosperous, and in full possession of an economy that is competitive, dynamic, robust and resilient" ${ }^{\prime 1}$

\footnotetext{
${ }^{50}$ Puteri Nemie Jahn Kassim, Medical Negligence Law in Malaysia 82 (Rev.2008).

51 [1967] 2 MLJ 45.

52 [1997] 1 All ER 871 at. P.873.

53 [1970] 2 MLJ 171.

54 [2002] 1 MLJ 484; [2002] 5 MLJ 167.

${ }_{55}$ Puteri Nemie Jahn Kassim, Medical Negligence Law in Malaysia 30 (Rev.2008).

${ }^{56}$ Puteri Nemie Jahn Kassim, Medical Negligence Law in Malaysia 46-47 (Rev.2008).

${ }^{57}$ [1996] 4 MLJ 674.

58 [2007] 1 MLJ 593.

${ }^{59}$ [2007] 1 MLJ 593, at para. 36

${ }^{60}$ www.rsmi.com.my/.../The\%2010th\%20Malaysia\%20Plan\%202.pdf

${ }^{61}$ Abu Bakar Bin Suleiman, Working for Health 105 (1996).
} 


\section{Conclusion}

Health is a crucial condition to enjoy other human rights though usually encapsulated within the right to life. All human rights contain such actions as right to life, security to person, right to water, right to information, right to education, right to rood and nutrition, freedom of movement, right to participation, harmful traditional practices, freedom from violence, torture, slavery, freedom from discrimination and the right to privacy. Therefore, Health as human rights should be considered more seriously in national as well as international legal framework. International legal instruments consider health as fundamental human right to the highest attainable standard of living. Recently, the Malaysian government has taken some meaningful initiatives. It is urgent for the government to put more efforts to meet the global standards. In addition, the government should encourage the civic society to assist and co-operate with all initiatives relating to health issue.

\section{Bibliography}

[1]. Harding. Andrew. Constitutional landmarks in Malaysia: the first 50 years, 1957-2007. Petaling Jaya, Selangor Darul Ehsan : Malayan Law Journal.(2007).

[2]. R.H. Hickling. An Introduction to the Federal Constitution. Kuala Lumpur: Malaysian Law Publishers. (1982)

[3]. Mohamed Salleh. Selected Articles \& Speeches on Constitution, Law \& Judiciary. Kuala Lumpur: Malaysian Law Publishers. (1984).

[4]. Kevin YL Tan \& Thio Li-ann. Constitutional Law in Malaysia and Singapore. (2 $2^{\text {nd }}$ Ed.). Singapore: Butterworths Press; (1997).

[5]. Abdul Aziz Bari. Malaysian Constitution: A Critical Introduction. The Other Press. (2003).

[6]. Nik Rosnah Wan Abdullah. Regulating the Private Health Sector in Malaysia. Kuala Lumpur: University of Malaysia Press; (2005).

[7]. Puteri Nemie Jahn Kassim. Medical Negligence Law in Malaysia. Malaysia: Laser Press; Rev.2008

[8]. M.C Gupta. Health and Law: a Guide for Professionals and Activists. New Delhi: Kanishka Publication; (2002).

[9]. Detels, R,. Holland, W,. et al. Oxford Textbook of Public Health.( ${ }^{\text {rd }}$ Ed.). Oxford University Press, Oxford.(1997).

[10]. Mohammad Naqib Ishan Jan. Principles of Public International Law: A Modern Approach. Kuala Lumpur: IIUM Press; (2008).

[11]. The Universal Declaration of Human Rights, (1948).

[12]. (https://www.un.org/en/documents/udhr/ accessed on $20^{\text {th }}$ april, 2013)

[13]. International Covenant on Civil and Political Rights, (1966).

[14]. (http://treaties.un.org/doc/Publication/UNTS/Volume\%20999/volume-999-I-14668 English.pdf. accessed on 20th april, 2013)

[15]. Human Rights Watch, 'Laos: End Silence on 'Disappeared' Activist', 19 February 2013 http://www.hrw.org/news/2013/02/19/laos-end-silence-disappeared-activis accessed 2nd June 2013.

[16]. UNHCR Malaysia, 'UNHCR Lauds Malaysia for Accepting Persons Rescued at Sea', December 2012 http://www.unhcr.org.my/News_Views-@_PressRelease MVNoscoVictory.aspx accessed $2^{\text {nd }}$ June 2013.

[17]. Full text of the UN Declaration of Human Rights is available at http://www.un.org/en/documents/udhr/index.shtml accessed 2 March 2013. 